The University of Maine

DigitalCommons@UMaine

Articles

Speck Collection Page

1918

\title{
Penobscot Transformer Tales
}

Frank G. Speck

Follow this and additional works at: https://digitalcommons.library.umaine.edu/speckarticles

Part of the Anthropological Linguistics and Sociolinguistics Commons, Applied Linguistics Commons, Archaeological Anthropology Commons, Comparative and Historical Linguistics Commons, Folklore Commons, International and Intercultural Communication Commons, Linguistic Anthropology Commons, Phonetics and Phonology Commons, Semantics and Pragmatics Commons, Social and Cultural Anthropology Commons, Syntax Commons, and the Typological Linguistics and Linguistic Diversity Commons

\section{Repository Citation}

Speck, Frank G., "Penobscot Transformer Tales" (1918). Articles. 1.

https://digitalcommons.library.umaine.edu/speckarticles/1

This Article is brought to you for free and open access by DigitalCommons@UMaine. It has been accepted for inclusion in Articles by an authorized administrator of DigitalCommons@UMaine. For more information, please contact um.library.technical.services@maine.edu. 


\section{CHICAGO JOURNALS}

Penobscot Transformer Tales

Author(s): Frank G. Speck

Source: International Journal of American Linguistics, Vol. 1, No. 3 (Aug., 1918), pp. 187-244

Published by: The University of Chicago Press

Stable URL: http://www.jstor.org/stable/1262934

Accessed: 11/06/2013 10:22

Your use of the JSTOR archive indicates your acceptance of the Terms \& Conditions of Use, available at http://www.jstor.org/page/info/about/policies/terms.jsp

JSTOR is a not-for-profit service that helps scholars, researchers, and students discover, use, and build upon a wide range of content in a trusted digital archive. We use information technology and tools to increase productivity and facilitate new forms of scholarship. For more information about JSTOR, please contact support@jstor.org. 


\title{
International Journal of American Linguistics
}

\begin{tabular}{lll}
\hline Volume I & August, I9I8 & Number 3 \\
\hline \hline
\end{tabular}

\section{PENOBSCOT TRANSFORMER TALES}

\author{
By Frank G. Speck Dictated by Newell Lion
}

\section{INTRODUCTION}

$\mathrm{T}$ HE following material is part of a collection of mythological texts obtained from Newell Lion of the Penobscot tribe, at Oldtown, Me. After devoting parts of several years prior to I9Io to a general study of Penobscot ethnology, I fortunately joined forces with Mr. Lion, who through a life-long interest in his native literature, has become a sort of raconteur among the Indians. Our combined labors then narrowed down to a study of linguistics and mythology. I am glad to pay him well-deserved tribute by stating that he has shown the interest and natural ability of a scholar in our common work. Discounting the fact that he himself ranks as the principal informant among the older men, he was wise enough to consult other old people for corroborative and supplementary material. Consequently I feel quite safe in presenting this version of the transformer trickster-cycle as being fairly complete and typical so far as the Penobscot are concerned.

No previous attempt has been made to record texts in the Penobscot language, although Professor Prince has recorded some short texts in its near relative, Passama-

${ }^{1}$ J. D. Prince, The Differentiation Between the Penobscot and the Canadian Abenaki Dialects (A A 4 [1902] : 17-32).

${ }^{2}$ Penobscot, Gluskq'be; Wawenock, Gluskq'be; Passamaquoddy, Malecite, and Micmac, Glu'skap.

'S. T. Rand, Legends of the Micmacs (New York and London, 1894); F. G. Speck, "Some Micmac Tales from Cape Breton Island" (J A F L 28 : 59-69).

4W. H. Mechling, Malecite Tales (G S Can, Anthropological Series, No. 4); E. Jack, Maliseet Legends (J A F L 8 [1895]); and F. G. Speck, Some Malecite Tales (J A F L 30 [1917]). quoddy, and has occasionally remarked in comparison on characteristics of Penobscot grammar. ${ }^{1}$

In the versions of eastern Indian myths given by the authors, there is, however, an undertone of untrue if not inferior reconception, which takes away the smack of originality that every reader feels the true examples of native oral literature should possess. This is unfortunately the case with all the hitherto published material from this region. Without exception, it has been interpreted and rendered in an altered form. Irresponsibility for the intrinsic worth of the original must pass by before primitive literature is free to make its own appeal to the interest of students.

Among the tribes forming the Wabanaki, or north-eastern Algonkian group, the mythical personage known as the "Deceiver" 2 figures pre-eminently in the rôle of the transformer-trickster. Already a number of published versions of the hero-myth are available from the Micmac, ${ }^{3}$ the Malecite, ${ }^{4}$ and the Passamaquoddy, ${ }^{5}$ although the myths of the lastnamed people are not presented objectively enough nor recorded critically enough to be of much value for comparison. Incidentally I have also prepared another set, in text form, from the Wawenock. ${ }^{6}$ Accordingly, when

${ }^{5}$ C. G. Leland, Algonquin Legends of New England, or Myths and Folk-Lore of the Micmac, Passamaquoddy and Penobscot Tribes (Boston, I884); C. G. Leland and J. D. Prince, Kuloscap The Master and Other Algonkin Poems (New York and London, 1902).

'This small tribe formed a division intermediate in dialect between the Penobscot and Aroosaguntacook (St. Francis Abenaki), formerly living southwest of Penobscot Bay, and now settled at Becancour, P.Q. 
